\title{
CONCAVITY AND BOUNDS INVOLVING GENERALIZED ELLIPTIC INTEGRAL OF THE FIRST KIND
}

\section{TiE-Hong ZhaO, MiaO-Kun Wang* And Yu-Ming Chu}

Abstract. In the article, we provide a sufficient condition for value range of the constant $c$ such that the function $x \rightarrow \mathscr{K}_{a}(\sqrt{x}) / \log (c / \sqrt{1-x})$ is strictly concave on $(0,1)$ for $a \in(0,1 / 2]$, which generalize a very recently obtained result that the function $x \rightarrow \mathscr{K}(\sqrt{x}) / \log (c / \sqrt{1-x})$ is strictly concave on $(0,1)$ if and only if $c=e^{4 / 3}$. As applications, we present new bounds for $\mathscr{K}_{a}(x), \mathscr{K}_{a}\left(\sqrt{1-x^{2}}\right) / \mathscr{K}_{a}(\sqrt{x})$ and $\mathscr{K}_{a}\left(\sqrt{1-x^{2}}\right) \mathscr{K}_{a}(\sqrt{x})$, where $\mathscr{K}_{a}(x)$ is the generalized elliptic integral of the first kind and $\mathscr{K}(x)=\mathscr{K}_{1 / 2}(x)$.

Mathematics subject classification (2020): 33E05, 33C05.

Keywords and phrases: Gaussian hypergeometric function, generalized elliptic integrals, generalized Grötzsch ring function, Ramanujan constant function, concavity.

\section{REFERENCES}

[1] M. Abramowitz and I. A. Stegun, Handbook of Mathematical Functions with Formulas, Graphs, and Mathematical Tables, U.S. Government Printing Office, Washington, 1964.

[2] M. Adil Khan, M. Hanif, Z. A. Khan, K. Ahmad and Y.-M. Chu, Association of Jensen's inequality for s-convex function with Csiszár divergence, J. Inequal. Appl., 2019 (2019), Article 162, 14 pages.

[3] M. Adil Khan, N. Mohammad, E. R. Nwaeze and Y.-M. Chu, Quantum Hermite-Hadamard inequality by means of a Green function, Adv. Difference Equ., 2020 (2020), Article 99, 20 pages.

[4] M. Adil KhAN, J. PeČArIĆ, Y.-M. CHU, Refinements of Jensen's and McShane's inequalities with applications, AIMS Math., 5, 5 (2020), 4931-4945.

[5] G. D. Anderson, S.-L. Qiu, M. K. Vamanamurthy and M. Vuorinen, Generalized elliptic integrals and modular equations, Pacific J. Math., 192, 1 (2000), 1-37.

[6] G. D. Anderson, M. K. Vamanamurthy and M. Vuorinen, Functional inequalities for complete elliptic integrals and their ratios, SIAM J. Math. Anal., 21, 2 (1990), 536-549.

[7] G. D. Anderson, M. K. Vamanamurthy and M. Vuorinen, Functional inequalities for hypergeometric functions and complete elliptic integrals, SIAM J. Math. Anal., 23, 2 (1992), 512-524.

[8] G. D. Anderson, M. K. Vamanamurthy and M. Vuorinen, Conformal Invariants, Inequalities, and Quasiconformal Maps, John Wiley \& Sons, New York, 1997.

[9] M. U. Awan, N. Akhtar, S. Iftikhar, M. A. Noor, Y.-M. Chu, New Hermite-Hadamard type inequalities for n-polynomial harmonically convex functions, J. Inequal. Appl., 2020 (2020), Article 125,12 pages.

[10] M. U. Awan, N. Akhtar, A. Kashuri, M. A. Noor And Y.-M. Chu, $2 D$ approximately reciprocal $\rho$-convex functions and associated integral inequalities, AIMS Math., 5, 5 (2020), 4662-4680.

[11] M. U. Awan, S. Talib, Y.-M. Chu, M. A. Noor, K. I. Noor, Some new refinements of HermiteHadamard-type inequalities involving $\Psi_{k}$-Riemann-Liouville fractional integrals and applications, Math. Probl. Eng., 2020 (2020), Article ID 3051920, 10 pages.

[12] J. M. BORWEIN AND P. B. BORWEIN, The arithmetic-geometric mean and fast computation of elementary functions, SIAM Rev., 26, 3 (1992), 351-366.

[13] B. C. CARlson And J. L. Guatafson, Asymptotic expansion of the first elliptic integral, SIAM J. Math. Anal., 16, 5 (1985), 1072-1092. 
[14] Y.-M. ChU, Y.-F. QIU AND M.-K. WANG, Hölder mean inequalities for the complete elliptic integrals, Integral Transforms Spec. Funct., 23, 7 (2012), 521-527.

[15] Y.-M. ChU AND M.-K. WANG, Inequalities between arithmetic-geometric, Gini, and Toader means, Abstr. Appl. Anal., 2012 (2012), Article ID 830585, 11 pages.

[16] Y.-M. CHU AND M.-K. WANG, Optimal Lehmer mean bounds for the Toader mean, Results Math., 61, 3-4 (2012), 223-229.

[17] Y.-M. ChU, M.-K. WANG, Y.-P. JIANG AND S.-L. QIU, Concavity of the complete elliptic integrals of the second kind with respect to Hölder means, J. Math. Anal. Appl., 395, 2 (2012), 637-642.

[18] Y.-M. CHU, M.-K. WANG AND S.-L. QIU, Optimal combinations bounds of root-square and arithmetic means for Toader mean, Proc. Indian Acad. Sci. Math. Sci., 122, 1 (2012), 41-51.

[19] Y.-M. ChU, M.-K. WANG, S.-L. QIU AND Y.-P. JIANG, Bounds for complete elliptic integrals of the second kind with applications, Comput. Math. Appl., 63, 7 (2012), 1177-1184.

[20] T.-R. HUANG, B.-W. HAN, X.-Y. MA AND Y.-M. CHU, Optimal bounds for the generalized EulerMascheroni constant, J. Inequal. Appl., 2018 (2018), Article 118, 9 pages.

[21] T.-R. HuAnG, S.-Y. TAN, X.-Y. MA AND Y.-M. CHU, Monotonicity properties and bounds for the complete p-elliptic integrals, J. Inequal. Appl., 2018 (2018), Article 239, 11 pages.

[22] Y.-X. Li, M. A. Ali, H. Budak, M. Abbas and Y.-M. Chu, A new generalization of some quantum integral inequalities for quantum differentiable convex functions, Adv. Difference Equ., 2021 (2021), Article 225, 15 pages.

[23] Y.-X. Li, M. H. Al-Shbool, Y.-P. Lv, I. Khan, M. Riza Khan and A. Issakhov, Heat and mass transfer in MHD Williamson nano uid ow over an exponentially porous stretching surface, Case Stud. Therm. Eng., 26 (2021), Article ID 100975, 10 pages.

[24] Y.-X. Li, T. Muhammad, M. Bilal, M. Altaf Khan, A. Ahmadian and B. A. Pansera, Fractional simulation for Darcy-Forchheimer hybrid nanoliquid ow with partial slip over a spinning disk, Alex. Eng. J., 60 (2021), 4787-4796.

[25] Y.-X. Li, A. Rauf, M. Naeem, M. A. Binyamin and A. Aslam, Valency-based topological properties of linear hexagonal chain and hammer-like benzenoid, Complexity, 2021 (2021), Article ID 9939469,16 pages.

[26] Y.-X. Li, F. Shah, M. IJaz Khan, R. Chinram, Y. Elmasry and T.-C. Sun, Dynamics of Cattaneo-Christov double diffusion (CCDD) and arrhenius activation law on mixed convective ow towards a stretched Riga device, Chaos Solitons Fractals, 148 (2021), Article ID 111010, 5 pages.

[27] F. W. J. Olver, D. W. Lozier, R. F. Boisvert And C. W. Clark, NIST Handbook of Mathematical Functions, Cambridge University Press, Cambridge, 2010.

[28] W.-M. QIAN AND Y.-M. CHU, Sharp bounds for a special quasi-arithmetic mean in terms of arithmetic and geometric means with two parameters, J. Inequal. Appl., 2017 (2017), Article 274, 10 pages.

[29] W.-M. QIAN, Z.-Y. He AND Y.-M. ChU, Approximation for the complete elliptic integral of the first kind, Rev. R. Acad. Cienc. Exactas Fís. Nat. Ser. A Mat., 114, 2 (2020), 12 pages, https://doi.org/10.1007/s13398-020-00784-9.

[30] W.-M. QIAn, X.-H. Zhang AND Y.-M. ChU, Sharp bounds for the Toader-Qi mean in terms of harmonic and geometric means, J. Math. Inequal., 11, 1 (2017), 121-127.

[31] W.-M. QIAn, W. ZhANG AND Y.-M. CHU, Bounding the convex combination of arithmetic and integral means in terms of one-parameter harmonic and geometric means, Miskolc Math. Notes, 20, 2 (2019), 1157-1166.

[32] S.-L. QIU, X.-Y. MA AND Y.-M. ChU, Sharp Landen transformation inequalities for hypergeometric functions, with applications, J. Math. Anal. Appl., 474, 2 (2019), 1306-1337.

[33] S. Rashid, R. AShraf, M. A. Noor, K. I. NOOR AND Y.-M. ChU, New weighted generalizations for differentiable exponentially convex mapping with application, AIMS Math., 5, 4 (2020), 35253546.

[34] S. Rashid, İ. İşCAn, D. BAleanu, Y.-M. Chu, Generation of new fractional inequalities via $n$ polynomials s-type convexixity with applications, Adv. Difference Equ., 2020 (2020), Article 264, 20 pages.

[35] S. RASHID, F. JARAD AND Y.-M. ChU, A note on reverse Minkowski inequality via generalized proportional fractional integral operator with respect to another function, Math. Probl. Eng., 2020 (2020), Article ID 7630260, 12 pages.

[36] S. Rashid, F. Jarad, H. Kalsoom And Y.-M. ChU, On Pólya-Szegö and Ćebyšev type inequalities via generalized $k$-fractional integrals, Adv. Difference Equ., 2020 (2020), Article 125, 18 pages. 
[37] S. Rashid, M. A. Noor, K. I. NoOR AND Y.-M. CHU, Ostrowski type inequalities in the sense of generalized $\mathscr{K}$-fractional integral operator for exponentially convex functions, AIMS Math., 5, 3 (2020), 2629-2645.

[38] Y.-Q. Song, M. Adil Khan, S. Zaheer Ullah and Y.-M. Chu, Integral inequalities involving strongly convex functions, J. Funct. Spaces, 2018 (2018), Article ID 6595921, 8 pages.

[39] M.-K. WANG AND Y.-M. CHU, Refinements of transformation inequalities for zero-balanced hypergeometric functions, Acta Math. Sci., 37B, 3 (2017), 607-622.

[40] M.-K. WANG AND Y.-M. CHU, Landen inequalities for a class of hypergeometric functions with applications, Math. Inequal. Appl., 21, 2 (2018), 521-537.

[41] M.-K. Wang, H.-H. Chu AND Y.-M. CHu, Precise bounds for the weighted Hölder mean of the complete p-elliptic integrals, J. Math. Anal. Appl., 480, 2 (2019), Article ID 123388, 9 pages, https://doi.org/10.1016/j.jmaa.2019.123388.

[42] M.-K. WANG, Y.-M. CHU AND Y.-P. JiAng, Ramanujan's cubic transformation inequalities for zero-balanced hypergeometric functions, Rocky Mountain J. Math., 46, 2 (2016), 679-691.

[43] M.-K. WAng, H.-H. CHU, Y.-M. Li AND Y.-M. CHU, Answers to three conjectures on convexity of three functions involving complete elliptic integrals of the first kind, Appl. Anal. Discrete Math., 14 (2020), 255-271.

[44] M.-K. WANG, Y.-M. CHU AND S.-L. QIU, Sharp bounds for generalized elliptic integrals of the first kind, J. Math. Anal. Appl., 429, 2 (2015), 744-757.

[45] M.-K. WAng, Y.-M. CHU, S.-L. QIU AND Y.-P. JiAng, Bounds for the perimeter of an ellipse, J. Approx. Theory, 164, 7 (2019), 928-937.

[46] M.-K. WAng, Y.-M. ChU, Y.-F. QIU AND S.-L. QIU, An optimal power mean inequality for the complete elliptic integrals, Appl. Math. Lett., 24, 6 (2020), 887-890.

[47] M.-K. WANG, Y.-M. CHU AND W. ZHANG, Monotonicity and inequalities involving zero-balanced hypergeometric function, Math. Inequal. Appl., 22, 2 (2019), 601-617.

[48] M.-K. Wang, Y.-M. Chu AND W. Zhang, Precise estimates for the solution of Ramanujan's generalized modular equation, Ramanujan J., 49, 3 (2019), 653-668.

[49] M.-K. WANG, Z.-Y. HE AND Y.-M. CHU, Sharp power mean inequalities for the generalized elliptic integral of the first kind, Comput. Methods Funct. Theory, 20, 1 (2020), 11-124.

[50] M.-K. WANG, M.-Y. Hong, Y.-F. XU, Z.-H. SHEN AND Y.-M. CHU, Inequalities for generalized trigonometric and hyperbolic functions with one parameter, J. Math. Inequal., 14, 1 (2020), 1-21.

[51] M.-K. WANG, Y.-M. Li AND Y.-M. CHU, Inequalities and infinite product formula for Ramanujan generalized modular equation function, Ramanujan J., 46, 1 (2018), 189-200.

[52] J.-L. WANG, W.-M. QIAN, Z.-Y. HE AND Y.-M. CHU, On approximating the Toader mean by other bivariate means, J. Funct. Spaces, 2019 (2019), Article ID 6082413, 7 pages.

[53] M.-K. WANG, S.-L. QIU AND Y.-M. CHU, Infinite series formula for Hübner upper bound function with applications to Hersch-Pfluger distortion function, Math. Inequal. Appl., 21, 3 (2018), 629-648.

[54] M.-K. WANG, S.-L. QIU, Y.-M. CHU AND Y.-P. JiAnG, Generalized Hersch-Pfluger distortion function and complete elliptic integrals, J. Math. Anal. Appl., 385, 1 (2012), 221-229.

[55] G.-D. WANG, X.-H. ZHANG AND Y.-M. CHU, A power mean inequality for the Grötzsch ring function, Math. Inequal. Appl., 14, 4 (2011), 833-837.

[56] G.-D. Wang, X.-H. Zhang AND Y.-M. CHU, A power mean inequality involving the complete elliptic integrals, Rocky Mountain J. Math., 44, 5 (2014), 1661-1667.

[57] Z.-H. YANG AND Y.-M. CHU, A monotonicity property involving the generalized elliptic integral of the first kind, Math. Inequal. Appl., 20, 3 (2017), 729-735.

[58] Z.-H. YANG, Y.-M. CHU AND M.-K. WANG, Monotonicity criterion for the quotient of power series with applications, J. Math. Anal. Appl., 428, 1 (2015), 587-604.

[59] Z.-H. YANG, Y.-M. CHU AND W. ZHANG, High accuracy asymptotic bounds for the complete elliptic integral of the second kind, Appl. Math. Comput., 348 (2019), 552-564.

[60] Z.-H. YANG, W.-M. QIAN AND Y.-M. CHU, Monotonicity properties and bounds involving the complete elliptic integrals of the first kind, Math. Inequal. Appl., 21, 4 (2018), 1185-1199.

[61] Z.-H. YANG, W.-M. QIAN, Y.-M. CHU AND W. ZHANG, Monotonicity rule for the quotient of two functions and its application, J. Inequal. Appl., 2017 (2017), Article 106, 13 pages.

[62] Z.-H. YANG, W.-M. QIAN, Y.-M. CHU AND W. ZHANG, On rational bounds for the gamma function, J. Inequal. Appl., 2017 (2017), Article 210, 17 pages. 
[63] Z.-H. YANG, W.-M. QIAN, Y.-M. ChU AND W. Zhang, On approximating the error function, Math. Inequal. Appl., 21, 2 (2018), 469-479.

[64] Z.-H. YAng, W.-M. QIAN, Y.-M. ChU AND W. Zhang, On approximating the arithmeticgeometric mean and complete elliptic integral of the first kind, J. Math. Anal. Appl., 462, 2 (2018), $1714-1726$.

[65] Z.-H. YANG, W.-M. QIAN, W. Zhang AND Y.-M. ChU, Notes on the complete elliptic integral of the first kind, Math. Inequal. Appl., 23, 1 (2020), 77-93.

[66] Z.-H. YANG AND J.-F. TIAN, Convexity and monotonicity for elliptic integrals of the first kind and applications, Appl. Anal. Discrete Math., 13, 1 (2019), 240-260.

[67] Z.-H. Yang, W. Zhang AND Y.-M. ChU, Sharp Gautschi inequality for parameter $0<p<1$ with applications, Math. Inequal. Appl., 20, 4 (2017), 1107-1120.

[68] T.-H. ZHAO, Y.-M. CHU AND H. WANG, Logarithmically complete monotonicity properties relating to the gamma function, Abstr. Appl. Anal., 2011 (2011), Article ID 896483, 13 pages.

[69] T.-H. Zhao, L. Shi And Y.-M. ChU, Convexity and concavity of the modified Bessel functions of the first kind with respect to Hölder means, Rev. R. Acad. Cienc. Exactas Fís. Nat. Ser. A Mat. 114, 2 (2020), 14 pages, https://doi.org/10.1007/s13398-020-00825-3.

[70] T.-H. ZhaO, M.-K. WANG AND Y.-M. CHU, A sharp double inequality involving generalized complete elliptic integral of the first kind, AIMS Math., 5, 3 (2020), 4512-4528.

[71] T.-H.ZHAO, M.-K. WANG, W. ZhANG AND Y.-M. CHU, Quadratic transformation inequalities for Gaussian hypergeometric function, J. Inequal. Appl., 2018 (2018), Article 251, 15 pages. 